\title{
Physical Examination Group Identifier
}

National Cancer Institute

\section{Source}

National Cancer Institute. Physical Examination Group Identifier. NCI Thesaurus. Code C83349.

A character or string that represents a physical examination group. 